\title{
Evaluation of Various Pesticides for the Control of Aphids, Mites and Nematodes in Peppers ${ }^{1}$
}

\author{
Carlos Cruz, N. Acosta, J. Negrón and A. Armstrong ${ }^{2}$
}

\begin{abstract}
The effeciveness of several insecticides and nematicide-insecticides in the control of aphids, mites and nematodes in pepper cultivars Cubanelle and Blanco del Pais was determined in four field experiments in 1979, 1980 and 1981 at Isabela, Puerto Rico. In the first test, a significant control of the green peach aphid Myzus persicae was obtained, $48 \mathrm{~h}$ and 1 month after application. In the second test, the oxamyl L-treated plots were the least affected by pepper mite. In these plots some reduction in nematode population levels, especially in Rotylenchulus reniformis, was obtained. Highest yield increases of pepper cv. Cubanelle were obtained with $1.12 \mathrm{~kg} / \mathrm{ha}$ of oxamyl L (46\%), $1.68 \mathrm{~kg} / \mathrm{ha}$ of aldicarb $(41 \%)$, and $0.56 \mathrm{~kg} / \mathrm{ha}$ of oxamyl $(40 \%)$. In the third test, Blanco del Pais plants treated with oxamyl showed no mite damage, a normal stand, and the highest yields, as well as good nematode control. Plant stand from methamidophos-treated plots was similar to that of control plants although yields were somewhat lower. Production from acephate-treated plants was significantly lower than that from control plants. In the fourth test, no mite infestation was observed on oxamyl-treated cv. Cubanelle plants, where highest yields and a good nematode control were obtained. Similar yield increases were obtained with both dosages of aldicarb. In general, results indicate that the pepper mite causes considerable yield losses and that cultivar Blanco de Pais is more tolerant to mite damage than cv. Cubanelle.
\end{abstract}

\section{INTRODUCTION}

The demand for fresh vegetables and legumes in Puerto Rico has increased considerably during the past few years. In 1980-81, cash value of these crops produced locally was $\$ 18.9$ million. During the same year, the pepper crop from approximately 1,233 ha, was 2,649 metric tons. At present, the Island is supplying only $37 \%$ of the demand. Therefore, a substantial increase in pepper production is necessary.

In order to increase pepper production, pests that cause severe damage must be controlled. Nematodes, aphids and mites are among the most detrimental pests of pepper in Puerto Rico. Román et al (5) reported that Meloidogyne, Pratylenchus, Rotylenchulus, Helicotylenchus, Tylenchorhynchus, Trichodorus and other nematodes are commonly associated with vegetable crops in Puerto Rico. In 1970 yield losses of $46 \%$ were reportedly caused by nematodes in peppers in Puerto Rico. ${ }^{3}$ Greenhouse experiments conducted by Varela (6) demonstrated that 5,000 eggs and 2nd stage juveniles of $M$. incognita per plant significantly reduced plant growth of cultivars Blanco del País and Cubanelle. Higher inoculum

${ }^{1}$ Manuscript submitted to Editorial Board November 21, 1983

${ }^{2}$ Entomologist, Associate Nematologist, and Research Assistants, respectively, Department of Crop Protection, College of Agricultural Science, Mayagüez, P.R.

${ }^{3}$ Dr. Jessé Román, personal communication. 
levels $(20,000 ; 40,000$; and 80,000) caused death of most plants. Román et al (5) reported yield increases in pepper of 66 and $89 \%$ with applications of phenamiphos at 11.2 and $16.8 \mathrm{~kg} / \mathrm{ha}$, respectively.

Experimental data from other areas indicate the damage that nematodes cause to vegetable crops. Di Vitto and Lamberti (3) obtained significant yield increases $(28 \%)$ in pepper cv. Yolo Wonder over the control plots, with preplant applications of DD to the soil to which nematode control approaching $100 \%$ was attributed. Jaworski et al (4) increased yields of marketable pepper transplants $1,240 \%$ with fall applications of a methyl bromide-chlorpicrin gas mixture and DD-MENCS, which controlled nematodes, Pythium spp., Fusarium spp. and weeds.

Aphids such as Macrosipium (=Illinoia) pepperi (MacGillivray), the vector of blueberry shoestring virus, have been effectively controlled with insecticides. Whalon and Elsner (7) reported reduction of aphid numbers with ground applications of pirimicarb and acephate, whereas aerial applications of pirimicarb and methomyl produced better control 3 days afterward. Aerial application of methomyl, pirimicarb, methamidophos, carbofuran and acephate drastically reduced populations of the green peach aphid in Puerto Rico (1).

\section{MATERIALS AND METHODS}

Several pesticides were tested for the control of aphids, mites and nematodes in a Coto clay ( $\mathrm{pH} 6.7$ and $1.5 \%$ organic matter) at the Isabela Research and Development Center. These pesticides were used on pepper cultivars Cubanelle and Blanco del País in 1979, 1980 and 1981.

The first field test was conducted to evaluate several insecticides for the control of the green peach aphid (Myzus persicae) on variety Cubanelle. The trial was planted March 13, 1979. Plots consisted of three rows $6.1 \mathrm{~m}$ long $\times 0.9 \mathrm{~m}$ apart arranged in a randomized block design with four replicates per treatment. Treatments were as follows: methamidophos (Monitor 4E) at the rate of 0.56 and $1.12 \mathrm{~kg} / \mathrm{ha}$ (a.i), acephate (Orthene 75S) at 0.63 and $1.12 \mathrm{~kg}$, carbofuran (Furadan 10G) at 2.24 (2 weeks after planting) and $6.72 \mathrm{~kg}$ (5 weeks after the first application), methomyl (Lannate 90S) at $0.56 \mathrm{~kg}$, and Metasystox-R at $0.56 \mathrm{~kg} / \mathrm{ha}$. Treatments, with the exception of carbofuran, were applied weekly from April 3 to April 26 (4 applications). Aphids found on 25 leaves per plot were counted before treatment, $48 \mathrm{~h}$ after treatment and 1 month later.

In the second test, with Cubanelle variety, treatments were as follows: methamidophos (0.56 and $1.12 \mathrm{~kg}$ a.i.), permethrin (Ambush; 0.22 and $0.44 \mathrm{~kg}$ ), carbofuran (2.24 plus $3.36 \mathrm{~kg}$ applied as in the first test), aldicarb (Temik 10G) at 1.68 and $3.36 \mathrm{~kg}$ and ethoprop (Mocap 10G) at 3.36 and $6.72 \mathrm{~kg} / \mathrm{ha}$. Oxamyl at $0.56,1.12$ and $2.24 \mathrm{~kg} / \mathrm{ha}$ was applied to the foliage every week. 
Soil treatments (aldicarb and ethoprop) were applied March 27, 1980. Carbofuran was applied April 16 (first application) and May 23 (second application). The first application was made 2 to 4 weeks after transplanting, and the second, 5 weeks later, as indicated in the label for Delmarva Peninsula and South Jersey. Granular nematicides were hoed in 5-8 cm deep into the soil. Foliar treatments with oxamyl were applied April 18, 25; May 1, 9; June 6 and 13, 1980, whereas foliar treatments with methamidophos were applied July 9, 16, 23, 30 and August 6, 1980, when plants were already in production. These treatments were applied to get samples for residue determinations.

Experimental plots established March 28, 1980, consisted of three 6.0 $\mathrm{m}$ rows $0.9 \mathrm{~m}$ apart. This experiment consisted of 14 treatments and 4 replications arranged in a randomized complete block design. Plants were fertilized and irrigated as recommended for this crop in the area. Aphids (on 25 leaves/plot) were counted before treatment 1 month after applications. Two pounds $(0.91 \mathrm{~kg} / \mathrm{plot})$ of fruits were taken for residue analysis 21 days after the last application of carbofuran. Samples for determination of oxamyl residues were taken $0,3,7$, and 14 days after the last application, whereas samples for methamidophos analysis were taken 7 , 14 , and 21 days after the last application. Samples from control plots were also collected for residue determination. Two weeks after the last foliar application, visual evaluation of the plots was made by assigning an index of 1 to 5 where 1 represents normal plants and 5 those most deteriorated by mites.

Soil samples (250 $\mathrm{cm}^{3}$ per plot) for nematode assays were taken $15 \mathrm{~cm}$ deep before nematicide or insecticide application and 5 weeks afterward. The modified Christie and Perry method (2) was used to extract nematodes from the soil.

In 1981, two field experiments were established. The first one was initiated March 31, 1981 with cultivar Blanco del Pais, nine treatments replicated four times. Treatments were arranged in a randomized complete block design. Acephate, at 0.56 and $1.12 \mathrm{~kg} / \mathrm{ha}$, was applied for 6 weeks. Applications of $1.12 \mathrm{~kg} / \mathrm{ha}$ acephate for 4 weeks were combined with applications of $0.56 \mathrm{~kg} / \mathrm{ha}$ for 2 weeks. Methamidophos $4 \mathrm{E}$ at 0.56 and $1.12 \mathrm{~kg} / \mathrm{ha}$ was applied for 6 weeks and oxamyl $\mathrm{L}$ at $0.56,1.12$ and 2.24 was applied to the foliage for 7 weeks. The second experiment was initiated May 4, 1981 with cultivar Cubanelle. It included 15 treatments replicated four times and arranged in a partially balanced incomplete block design. Treatments were similar to those in the first test, except that 0.44 and 0.88 (a.i.) of permethrin, $1.12 \mathrm{~kg}$ (a.i.) of methamidophos for 6 weeks, $1.12 \mathrm{~kg}$ (a.i.) of acephate for 6 weeks, and $1.12 \mathrm{~kg}$ (a.i.) for 4 weeks plus $0.56 \mathrm{~kg}$ (a.i.) for 2 weeks were included. There were only six replications of oxamyl. Methodology and materials were similar for all 
experiments. Fruit samples for determination of acephate residues were collected 7 days after the last application. Methamidophos residues were collected 7 and 14 days after the last application.

Percentages of nematode control were statistically analyzed and differences between means evaluated for significance according to Student's " $t$ " or Duncan's new multiple range tests.

\section{RESULTS AND DISCUSSION}

Table 1 shows the results from the first test. All the chemicals controlled the green peach aphid (Myzus persicae). Insect counts $48 \mathrm{~h}$ and 1 month after the first application showed that aphid populations were drastically reduced, whereas in the control plots populations increased. No phytotoxicity was observed in any of the treated plants. A severe

TABLE 1.-Effects of insecticides and nematicide-insecticide on populations of the green peach aphid (Myzus persicae) on pepper cu. Cubanelle, March 1979, Isabela, Puerto Rico

\begin{tabular}{lcccc}
\hline \multirow{2}{*}{ Treatment } & \multirow{2}{*}{ Rate } & \multicolumn{3}{c}{ Number of aphids in 25 leaves/plot } \\
\cline { 3 - 5 } & $\mathrm{kg} / \mathrm{ha}(\mathrm{a} . \mathrm{i})$ & $\begin{array}{c}\text { Before } \\
\text { treatment }\end{array}$ & $48 \mathrm{~h}$ after & $\begin{array}{c}\text { One month } \\
\text { after }\end{array}$ \\
\hline Methamidophos 4E & 0.56 & 10.0 & $0.0^{1} \mathrm{a}$ & $0.0 \mathrm{a}$ \\
Methamidophos 4E & 1.12 & 5.5 & $0.0 \mathrm{a}$ & $0.0 \mathrm{a}$ \\
Acephate 75S & 0.63 & 3.7 & $0.0 \mathrm{a}$ & $0.0 \mathrm{a}$ \\
Acephate 75S & 1.12 & 6.0 & $1.5 \mathrm{a}$ & $0.0 \mathrm{a}$ \\
Carbofuran 10G & $2.24+3.36$ & 10.7 & $0.5 \mathrm{a}$ & $0.0 \mathrm{a}$ \\
Carbofuran 10G & $4.48+6.72$ & 3.7 & $0.5 \mathrm{a}$ & $0.0 \mathrm{a}$ \\
Methomyl 90S & 0.56 & 6.0 & $0.5 \mathrm{a}$ & $0.5 \mathrm{a}$ \\
Metasyxtox R & 0.56 & 10.7 & $0.0 \mathrm{a}$ & $0.0 \mathrm{a}$ \\
Control & - & 15.2 & $6.7 \mathrm{~b}$ & $42.3 \mathrm{~b}$ \\
\hline
\end{tabular}

${ }^{1}$ Values in the same column followed by the same letter do not differ statistically $(\mathrm{P}=$ $0.05)$, according to Duncan's multiple range test.

attack of Phytophthora spp. and other stem pathogens at early stages destroyed most of the plants; therefore, no yield data was recorded.

In the second test, infestation index in the plots treated with the lowest and highest rates of oxamyl, was significantly lower than in the control plots (table 2). The remaining treated plots showed a high degree of mite infestation. Yields from oxamyl- and from aldicarb-treated plots at rates of 1.12 and $1.68 \mathrm{~kg} / \mathrm{ha}$, respectively were significantly higher than those from the control plots. Similarly, the highest number of fruits were obtained from these plots. Plots treated with $1.12 \mathrm{~kg} / \mathrm{ha}$ of methamidophos showed symptoms of phytotoxicity and premature defoliation. Nematode control was generally poor in this test. Nevertheless, some control was obtained in plots treated with oxamyl $\mathrm{L}$ and in those treated with $6.72 \mathrm{~kg} / \mathrm{ha}$ of ethoprop. 
TABLE 2.-Effects of applications of pesticides on mite and nematode populations, plant stand and yield of pepper cultivar Cubanelle, August 1980, Isabela, P.R.

\begin{tabular}{|c|c|c|c|c|c|c|c|}
\hline \multirow{2}{*}{ Treatment. } & \multirow[b]{2}{*}{ Rate } & \multirow{2}{*}{$\begin{array}{c}\text { Mite } \\
\text { infestation }^{1}\end{array}$} & \multirow{2}{*}{$\begin{array}{l}\text { Visual } \\
\text { index }^{2}\end{array}$} & \multicolumn{2}{|c|}{ Yield/plot (Fruits) } & \multicolumn{2}{|c|}{ Percent } \\
\hline & & & & Number & Weight & $\begin{array}{c}\text { Yield } \\
\text { increase }\end{array}$ & $\begin{array}{c}\text { Nematode } \\
\text { control }^{3}\end{array}$ \\
\hline & $\mathrm{kg} / \mathrm{ha}$ (a.i.) & $(0-5)$ & $(1-5)$ & & $\mathrm{kg}$ & & \\
\hline Oxamyl L & 0.56 & $2.1 \mathrm{a}$ & $2.6 \mathrm{ab}$ & $1000.7 \mathrm{abc}$ & $42.9 \mathrm{abc}$ & 40 & 5 \\
\hline Oxamyl L & 2.24 & $2.1 \mathrm{a}$ & $2.1 \mathrm{ab}$ & $975.0 \mathrm{abc}$ & $41.3 \mathrm{abc}$ & 18 & 41 \\
\hline Oxamyl L & 1.12 & $2.5 \mathrm{ab}$ & $2.6 \mathrm{ab}$ & $1158.8 \mathrm{bc}$ & $51.4 \mathrm{~b}$ & 46 & 24 \\
\hline Carbofuran 10G & $2.24+3.36$ & $3.8 \mathrm{bc}$ & $3.3 \mathrm{bc}$ & $948.2 \mathrm{abc}$ & $40.5 \mathrm{abc}$ & 8 & - \\
\hline Carbofuran $10 \mathrm{G}$ & $4.48+6.72$ & $4.1 \mathrm{c}$ & $3.8 \mathrm{c}$ & 806.4 a & $33.1 \mathrm{ac}$ & - & - \\
\hline Methadomidophos 4E & 0.56 & $3.2 \mathrm{bc}$ & $3.4 \mathrm{c}$ & $952.5 \mathrm{abc}$ & $42.1 \mathrm{abc}$ & 14 & - \\
\hline Methadomidophos 4E & 1.12 & $2.8 \mathrm{ab}$ & $4.5 \mathrm{c}$ & 795.7 a & $36.6 \mathrm{ac}$ & 8 & - \\
\hline Aldicarb $10 \mathrm{G}$ & 1.68 & $3.2 \mathrm{bc}$ & $3.4 \mathrm{c}$ & $1103.5 \mathrm{bc}$ & $50.2 \mathrm{~b}$ & 41 & - \\
\hline Aldicarb 10G & 3.36 & $2.6 \mathrm{ab}$ & $3.2 \mathrm{ab}$ & $1041.6 \mathrm{abc}$ & $45.9 \mathrm{abc}$ & 27 & - \\
\hline Ethoprop $10 \mathrm{G}$ & 3.36 & $3.1 \mathrm{bc}$ & $3.1 \mathrm{ab}$ & 890.4 ac & $37.3 \mathrm{ac}$ & 4 & - \\
\hline Ethoprop 10G & 6.72 & $2.9 \mathrm{bc}$ & $3.2 \mathrm{ab}$ & $858.3 \mathrm{ac}$ & $39.5 \mathrm{abc}$ & 7 & 40 \\
\hline Permethrin 2E & 0.22 & $2.8 \mathrm{ab}$ & $3.1 \mathrm{ab}$ & $1023.5 \mathrm{abc}$ & $47.2 \mathrm{bc}$ & 24 & - \\
\hline Permethrin 2E & 0.44 & $2.4 \mathrm{ab}$ & $2.7 \mathrm{ab}$ & $1052.2 \mathrm{bc}$ & $46.1 \mathrm{abc}$ & 33 & - \\
\hline Control & - & $3.3 \mathrm{bc}$ & $2.9 \mathrm{ab}$ & $91.6 \mathrm{a}$ & $34.1 \mathrm{ac}$ & - & - \\
\hline
\end{tabular}

${ }^{1} 5=$ Heavy mite infestation, $0=$ mite free plants; values in the same columns followed by the same letter do not differ statistically $(\mathrm{P}=$ $0.05)$, according to student's $t$ test.

${ }^{2}$ Scale of 1 to $5,1=$ normal plants and $5=$ the most affected.

${ }^{3}$ Percent nematode control $=$ initial population (ip) - final population $(\mathrm{fp}) \div \mathrm{ip} \times 100$. 
Table 3 shows data from results in the third test. Cultivar Blanco del Pais showed the least symptoms of mite damage and normal plant stand in plots treated with oxamyl. Highest yields were obtained from those plots. No other insect pest was observed in the plots. None of the other chemicals controlled mites effectively. A nematode control of 34.5 and $65 \%$ was obtained with oxamyl L. Plant stand from methamidophostreated plots were similar to those of control plants although yields were somewhat lower. Yields from acephate-treated plots were lower than from control plots. Plant stand in such plots was the poorest and it was very difficult to differentiate symptoms of phytotoxicity from those caused by mites. The highest yield increases $(26.9,23$ and $22 \%$ ) in cv. Cubanelle were obtained with $1.12 \mathrm{~kg} / \mathrm{ha}$ of oxamyl L, and with 1.68 and $3.36 \mathrm{~kg} / \mathrm{ha}$ of aldicarb, respectively (table 4). The best plant stand, as well as no symptoms of mite attack, was observed in these plots. Nematode control ranged from 72 and $92 \%$. The best control was obtained with the lowest and intermediate rates of oxamyl L. Some mite control was observed in plots treated with aldicarb, where plants had good stand and light mite attack. Plants from acephate- permethrin- and methamidophos-treated plots had the poorest stand and the heaviest mite infestation.

The data from the experiments herein reported demonstrate that aphids, mites and nematodes play a very important role in reducing pepper production in Puerto Rico. Results from the first test are similar to those reported by Whalon and Elsner (7), who controlled the aphid $M$. pepperi with applications of pirimicarb, acephate and methomyl. Similarly, Cruz (1) reduced green peach aphid populations in pepper with applications of the above mentioned pesticides. Oxamyl $\mathrm{L}$ has proved to be effective for the control of both mites and nematodes.

\section{RESUMEN}

Durante 1979, 1980 y 1981 varios insecticidas y nematicida-insecticidas se evaluaron para investigar su eficacia para controlar áfidos, ácaros y nematodos en las cultivares de pimiento Cubanelle y Blanco del País. En el primer ensayo se obtuvo un control significativo del áfido verde del melocotón, Myzus persicae, en todos las parcelas, 48 h y 1 mes después de la aplicación. En el segundo ensayo las parcelas tratadas con oxamyl fueron las menos afectadas por los ácaros y se redujo la población de nematodos, especialmente de Rotylenchulus reniformis. Se obtuvo, además, un buen control de nematodos en las parcelas tratadas con $6.72 \mathrm{~kg} /$ ha de ethoprop. Los mayores rendimientos se obtuvieron en las parcelas tratadas con $0.88 \mathrm{~kg} / \mathrm{ha}$ de oxamyl (46\%), $1.68 \mathrm{~kg} / \mathrm{ha}$ de aldicarb $(41 \%)$ y $0.22 \mathrm{~kg} / \mathrm{ha}$ de oxamyl (40\%). En un tercer ensayo, las parcelas tratadas 
TABLE 3.-Effects of applications of insecticides and nematicide-insecticides on pest control and yields of pepper cv. Blanco del Pais, June 1981, Isabela, Puerto Rico

\begin{tabular}{|c|c|c|c|c|c|c|c|}
\hline \multirow[b]{2}{*}{ Treatment } & \multirow[b]{2}{*}{ Rate } & \multirow{2}{*}{$\begin{array}{c}\text { Mite } \\
\text { infestation }\end{array}$} & \multirow{2}{*}{$\begin{array}{l}\text { Visual } \\
\text { index }\end{array}$} & \multicolumn{2}{|c|}{ Yield/plot (Fruits) } & \multicolumn{2}{|c|}{ Percent } \\
\hline & & & & Number & Weight & $\begin{array}{c}\text { Yield } \\
\text { increase }\end{array}$ & $\begin{array}{c}\text { Nematode } \\
\text { control }^{3}\end{array}$ \\
\hline & $\mathrm{kg} / \mathrm{ha}$ (a.i.) & $(0-5)$ & $(1-5)$ & & $\mathrm{kg}$ & & \\
\hline Acephate $75 \mathrm{~S}$ & $1.12 / 4 w k+0.56 / 2 w k$ & $5 \mathrm{a}$ & 3.3 & $946.3 \mathrm{ac}$ & $46.72 \mathrm{ac}$ & -2.6 & 25 \\
\hline Acephate $75 \mathrm{~S}$ & $1.12 / 6 \mathrm{wk}$ & $5 \mathrm{a}$ & 2.9 & $849.3 \mathrm{a}$ & $39.63 \mathrm{a}$ & -17.4 & 29 \\
\hline Acephate $75 \mathrm{~S}$ & $0.56 / 6 \mathrm{wk}$ & $5 \mathrm{a}$ & 2.7 & $934.0 \mathrm{ac}$ & $43.77 \mathrm{ac}$ & -8.8 & 25 \\
\hline Methamidophos 4E & $0.56 / 6$ wk & $5 \mathrm{a}$ & 2.7 & $923.8 \mathrm{ac}$ & $40.13 \mathrm{a}$ & -16.4 & 50 \\
\hline Methamidophos 4E & $1.12 / 6 \mathrm{wk}$ & $5 \mathrm{a}$ & 2.9 & $910.5 \mathrm{ac}$ & $41.09 \mathrm{a}$ & -14.4 & 17 \\
\hline Oxamyl L & $0.56 / 7 \mathrm{wk}$ & $0 \mathrm{~b}$ & 2.4 & $1379.3 \mathrm{~b}$ & $58.61 \mathrm{~b}$ & 22.1 & 34 \\
\hline Oxamyl L & $1.12 / 7 \mathrm{wk}$ & $a b$ & 2.0 & $1269.3 \mathrm{bc}$ & $53.89 \mathrm{c}$ & 12.3 & 65 \\
\hline Oxamyl L & $2.24 / 7 \mathrm{wk}$ & $0 \mathrm{~b}$ & 2.3 & $1383.3 \mathrm{~b}$ & $58.70 \mathrm{c}$ & 22.3 & 35 \\
\hline Control & - & $5 \mathrm{a}$ & 2.8 & $1128.3 \mathrm{c}$ & $47.99 \mathrm{ac}$ & - & 0 \\
\hline
\end{tabular}

${ }^{1} 5=$ Heavy mite infestation, $0=$ mite free plants; values in the same column followed by the same letter do not differ statistically $(\mathrm{P}=$ $0.05)$, according to Duncan's multiple range test.

${ }^{2}$ Scale of 1 to $5,1=$ normal plants and $5=$ the most affected.

${ }^{3}$ Percent nematode control $=$ initial population (ip) - final population $(\mathrm{fp}) \div \mathrm{ip} \times 100$. 


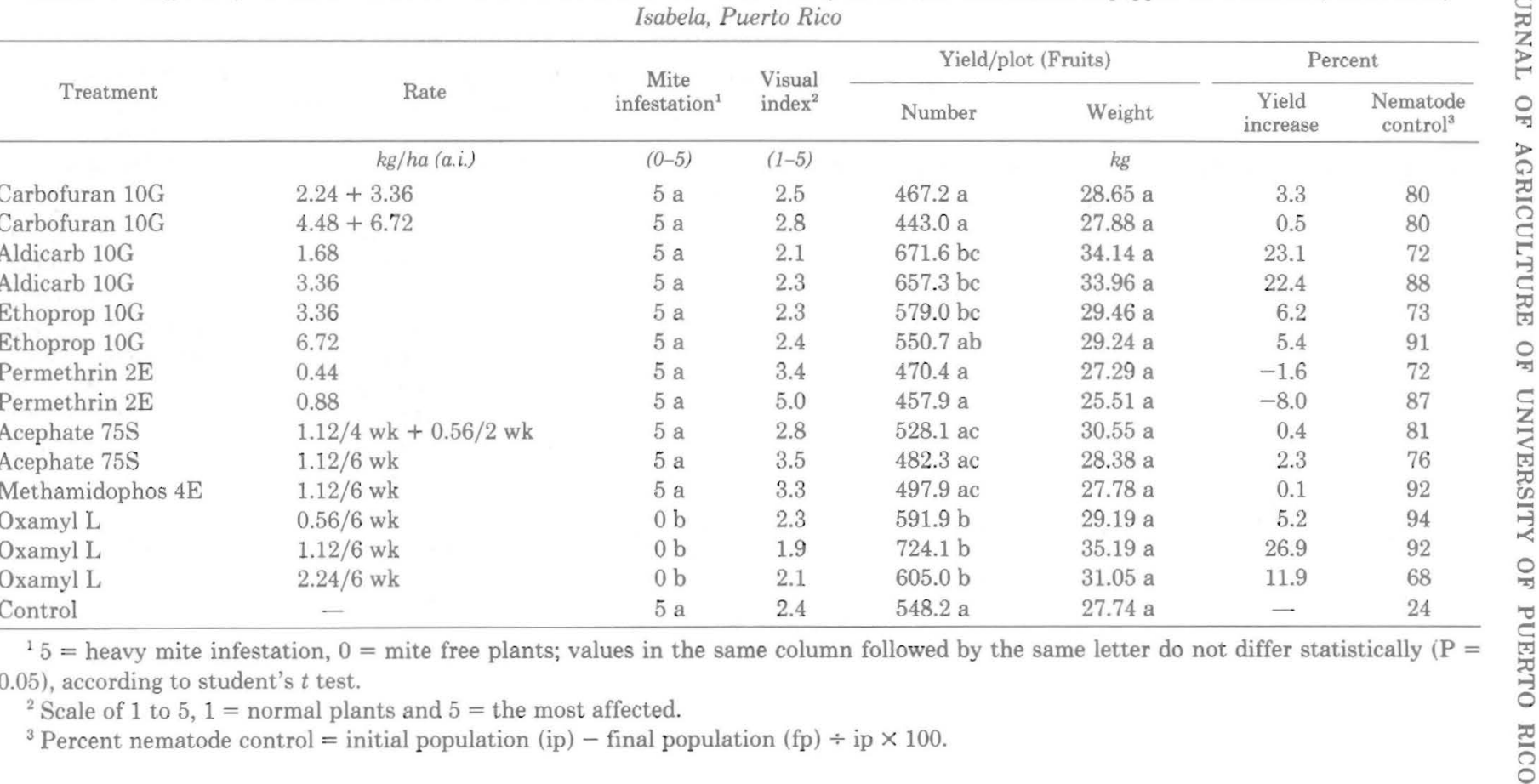


con la dosis más alta de oxamyl no mostraron daño atribuible a ácaros, tuvieron un buen crecimiento y desarrollo, produjeron los rendimientos más altos y además mostraron un buen control de nematodos. Las plantas de parcelas tratadas con methamidophos tuvieron un crecimiento similar al de las plantas testigo, sin embargo las producciones fueron más bajas. La producción en las parcelas tratadas con las dosis más altas de acephate fue más baja que las de las testigo. En el cuarto ensayo, los resultados demonstraron que no hubo infestación por ácaros en las plantas tratadas con oxamyl, las que produjeron los mayores rendimientos y el mejor control de nematodos. Aumentos similares en producción se obtuvieron con ambas dosis de aldicarb. Los resultados de los experimentos indican que el ácaro del pimiento causa pérdidas en producción considerables en Puerto Rico. La cultivar Blanco del País mostró una mayor tolerancia al ácaro, Por otro lado, la cultivar Cubanelle no recuperó del ataque del ácaro.

\section{LITERATURE CITED}

1. Cruz, C., 1974. Evaluation of new insecticides for control of the Green Peach Aphid, Myzus persicae (Sulzer) on sweet pepper in Puerto Rico, J. Agric. Univ. P.R. 58 (4): 489-90.

2. Christie, J. R. and V. G. Perry, 1951. Removing nematodes from soil, Proc. Helminthol. Soc.Wash. 18: 106-08.

3. Di Vitto, M. and F. Lamberti, 1980. Chemical Control of Meloidogyne incognita on Pepper in Apulia, Nematol. Med. 8 (1): 81-83.

4. Jaworski, C. A., S. C. Phatak, S. M. McCarter and A. W. Johnson, 1980. Pepper, Tomato and Cabbage Transplant Production and Soil Pest Control in Relation to Fall Broadspectrum Soil Fumigation and Nematicide Application, HortScience 15 (3): 383 (Abstr.)

5. Román, J., X. Rivas, I. Reyes G. Mangual, 1972. Estudios sobre el uso de nematicidas en hortalizas, Nematrópica 1: 23 (Abstr.).

6. Varela, F., 1983. Interacción de Meloidogyne incognita y Fusarium solani en la marchitez del pimiento (Capsicum annuum L.), M. S. thesis, Univ. P. R., Mayagüez.

7. Whalon, M. E. and E. A. Elsner, 1982. Impact of Insecticides on Illinoia pepperi and its Predator, J. Econ. Entomol. 75: 356-58. 